\title{
RAVASZ LÁSZLÓ, A SZÓNOK
}

\author{
$(1882-1975)$
}

\author{
A. JÁSZÓ ANNA
}

Ravasz László erdélyi születésű református püspök, filozófiai és teológiai író a felsőfokú tanulmányait Kolozsvárott, majd Berlinben végezte. Pályája elején a kolozsvári református teológia professzora. 1921-től Budapesten lelkészkedett (a Kálvin téren); 1925-1949 között az MTA tagja, s bár a kommunista államvezetés megfosztotta akadémiai tagságától, 1989-ben posztumusz visszakapta; 1948-ban püspöki tisztségéről lemondatták, 1953-ban lelkészi állásából nyugdíjazták. Az egyik legnagyobb magyar egyházi szónok, retorikaelméleti író, ám ebből a szempontból életművét még nem értékelték kellő alapossággal, bár homiletikájáról nemrégiben megjelent egy alapos tanulmány. ${ }^{1}$ Munkássága kétségkívül nemzetközi szempontból is kiemelkedő: számos olyan gondolat olvasható a 20. század első felében írt műveiben, amelyeket a 20. század második felének híres külföldi retorikusai fogalmaztak meg. Az alábbi írás felhívja a figyelmet ezekre a kapcsolatokra, s ezáltal Ravasz László gondolatainak korszerüségét hangsúlyozza; ugyanakkor azt is hangsúlyozzuk, hogy műveiben benne van a háromezer éves retorika ismerete, ebből a szempontból összegezőnek tekinthető. ${ }^{2}$

\section{HOMILETIKÁJA}

1915-ben Pápán jelent meg a Református Egyházi Könyvtár XI. köteteként homiletikája, A gyülekezeti igehirdetés elmélete. A 497 oldalas mű három és fél évig készült, történeti részéből kb. nyolc fejezet eredeti forrástanulmányokon nyugszik. Bevezetésből és négy nagy részből áll: I. Az igehirdetés történetének föirányai (17-239); II. A gyülekezeti igehirdetés alapelvei (240-293); III. Az igehirdetés mint

\footnotetext{
${ }^{1}$ Literáty Zoltán (szerk.): Száz év után Ravasz László homiletikájáról. Budapest, KRE - L'Harmattan, 2020. (A 2015-ben tartott centenáriumi konferencia anyaga.)

${ }^{2}$ Ravasz Lászlóról lásd Adamik Tamás (föszerk.): Retorikai lexikon. Pozsony, Kalligram, 2010, 989-995; Adamik Tamás - A. Jászó Anna - Aczél Petra: Retorika. Budapest, Osiris, 2004, 173175; Adamikné Jászó Anna: Klasszikus magyar retorika. Budapest, Holnap Kiadó, 2013, 179-181.
} 
értékrendszer (294-379); IV. Az igehirdetés mint müalkotás (380-486). Felosztását a következőképpen indokolja meg: „Nézetünk szerint az igehirdetés nem egyéb, mint az ige örök javainak olyan művészi felhasználása, amellyel az embert és a gyülekezetet Isten terve és akarata szerint eszményi állapot felé visszük. Tehát az a kérdés, mik ezek a javak és hogyan használjuk fel. Ezek a javak sem nem biblia, sem nem hitvallás, sem nem dogmatika és etika, sem nem történet, sem nem mindennapi élet, hanem mindezek együtt: s még valami egyéb; az, amit röviden homiletikai értékeknek nevezünk. A homiletikai értékek érvényesülésének útját, amint az igazságok a müvészet síkján az etikai régiókba érkeznek, ismét külön kell tárgyalnunk, mert ez előbbihez képest külön tárgy is lesz.” Az első rész, a történeti fejezet a prófétaságtól, Jézus és Pál igehirdetésétől ível végig az egyháztörténeten a magyar protestáns igehirdetésig, saját koráig; végül ismerteti a magyar homiletikákat. A második rész először az igehirdetés lényegével foglalkozik (az igehirdetés mint istentiszteleti tényező, a prédikáció mint szónoki alkotás, az épülés), majd az igehirdető személyiségéről, hitéről, teológiai felfogásáról, végül a gyülekezetről (a hallgatóság lélektanáról, különbözőségéről) értekezik. A harmadik rész témái: az Ige mint a prédikáció tárgya; a homiletikai értékek forrása: a Biblia; a textus magyarázása, a textus felvételének szabályai; a homiletikai érték az egyház életében: itt foglalkozik az egyházi ünnepkörökkel, a kultikus alkalmakkal, a tulajdonképpeni alkalmi beszédek és a liturgialis (pl. házasságkötési, temetési) beszédek anyagával.

A negyedik rész a tulajdonképpeni retorika: a) Az egyházi beszéd szerkezete, a tétel mivolta és alkata; általános és különös tételek; a tétel megfogalmazása; a beszéd elágaztatása logikai szempontból; a beszéd elágaztatása retorikai szempontból; homilia és sermo; a bevezetés; a befejezés. b) Az egyházi beszéd kidolgozása: a megértés vagy magyarázás; a bizonyítás; a rábírás; a rábírás lélektani szempontból; a rábírás értékelméleti szempontból; a stílus mivolta és fajai; a kifejtő stílus általános követelményei; a szónoki stílus eszközei; az egyházi beszéd stílusának különös jellege. c) Az egyházi beszéd előadása.

Homiletikája gazdag tartalmát itt nincsen mód ismertetni, csak néhány olyan problémát érintünk, amelyekkel megelőzte korát. Hosszasan és érdekesen, lélektani megalapozással ír a hallgatóságról. „Gyülekezet alatt mindig valami elvont létezőt értett (az igehirdetés), amelynek kötelessége volt az érvek súlya alatt meggyözetni, de nem gondoltak arra, hogy a gyülekezet nem elvont létezö, hanem élő, egyéni valóság, amelynek megismerése elsőrangú szükség és kötelesség" (279). Nem csatlakozik a Wundt-féle néplélektanhoz, hanem azt mondja, hogy „a hallgatóság mindig az ember maga" (281). Az igehirdetés célja az, hogy a hallgatóság lelkében valamiféle változás menjen végbe, épülés, életgyarapodás. Lélektanilag ez a folyamat a hiány, a pótlék és a meggyarapodás mozzanataiból áll. „Az élet nem egyéb, mint értékkeresés, értékfogyasztás és értékfejlesztés. Minden öntudatos élet minéműségét, természetét, sőt programját értékei mutatják” (283). „Két dolgot kell 
az igehirdetésnek elvégeznie: először ott, ahol nincs meg az isteni hiányérzete, ezt felébreszteni; másodszor, ahol a hiányérzetek megvannak, felmutatni, szemléltetni az értékeknek azt a rendszerét, amely e hiányok boldog pótlását adja” (285). Mindez szavakkal történik, s ebben van az igehirdetés áldása és átka. „Áldása, mert lehetővé teszi, hogy a szó hatalma által pozitív javakat közöljünk, amennyiben a szó valóságot jelent, olyan valóságot, amelyben lelkünk a maga örök hiányainak pótlékát leli fel. A szavak a valóságok nagykövetei, s mint ilyenek, küldőik helyett cselekszenek: vagy meglevő hiányokat pótolnak, vagy újakat ébresztenek, szóval quietivumokat, vagy pedig motívumokat adnak. Azonban szó és a jelentett tárgy között egész világ van, mint az élő ember és arcképe között; szinte azt lehet mondani, hogy külön életet élnek. [...] Tehát az igehirdetésnek második nagy feladata, hogy a szavaktól a tárgyakig vezessen, vagyis e megszokott, üres formákból feltárja a valóságokat, azt az életet, amelyik éppen nekem van szánva, hogy az én fogyatékos, töredék életemet kiegészítse” (285-286). - Ha a változás helyett az azonosulás (identificatio) terminust használjuk, akkor Kenneth Burke ${ }^{3}$ alaptételénél vagyunk. A hiány fogalma a retorikai szituáció fogalmához kapcsolódik, melyet Lloyd Bitzer $^{4}$ fogalmazott meg. Ha pedig a szavak mögötti valóság felidézését említjük, akkor a jelenlévőség Perelman-féle ${ }^{5}$ terminusa jut eszünkbe, az értékek hangsúlyozása kapcsán pedig Richard Weaver ${ }^{6}$ etikai alapú elmélete. A hallgatóságot pedig a lelkipásztori tevékenységgel lehet megismerni, a lelkipásztorkodás része tehát az igehirdetésnek.

A stílus szerinte a legkényesebb pont a müalkotás elméletében. Buffont idézi: a stílust javítani annyi, mint jobbá tenni a gondolatokat. „Ennek pedig oka az, hogy a gondolat, mint jelentések viszonya, érzéki formát a nyelvben ölt, azonban nemcsak a gondolat formálja a stílust, hanem a nyelv is a gondolatot” (448). A stílus

\footnotetext{
${ }^{3}$ Kenneth Duva Burke (1897-1993) amerikai polihisztor, retorikus. Retorikaelméletének alapvető kategóriája az azonosulás (identification), amely azt az egyesítőerőt jelenti, amely a retorika eszközeivel közelebb hozza egymáshoz az embereket. Föbb retorikai művei: A Grammar of Motives. Cleveland, 1945; A Rhetoric of Motives. New York, 1950.

${ }^{4}$ Lloyd F. Bitzer: „Rhetorical Situation.” Philosophy and Rhetoric, 1968, 1-14. Minden retorikai szituációnak három eleme van: a szükség, amely hiány vagy probléma; a hallgatóság, amely érdekelt a hiány megszüntetésében, a probléma megoldásában; és a kényszer, amely a szónokot arra indítja, hogy hasson a hallgatóságra. A hallgatóság szerepét, megismerésének fontosságát mindegyik modern szerző fontosnak tartja.

${ }^{5}$ Chaïm Perelman (1912-1984), brüsszeli professzor, a XX. század Aristotelésének nevezik. Fő műve: La nouvelle rhétorique. Traité de l'argumentation. Paris, 1958 (Lucie Olbrechts-Tytecával). Rövid összefoglalása magyarul is olvasható: A retorika birodalma. Retorika és érvelés. Ford. Major Hajnalka. Budapest, 2018 (1977). Retorikájának egyik alapkategóriája a jelenlévőség, az időben és térben távol lévő dolgok felidézése.

${ }^{6}$ Richard M. Weaver (1910-1953), amerikai retorikus, fö műve: The Ethics of Rhetoric. Chicago, 1953.
} 
meghatározását ekképp vezeti fel: „Alapjában minden szó valamely szemléletnek akusztikai egyenértékese volt, tehát a szó ősi formája a metafora, a szelleminek egy érzéki képpel való jelölése. Egész szókincsünk elhalt metaforákból áll, amelyekből kiveszett a szemlélet, s csak a külső burok maradt meg. A megmaradt szóképek pedig önálló, élő egységet, nyelvet alkotva, a maguk külön törvényei szerint alakultak, képződtek, koptak, de feladatuk mindig ugyanaz maradt: jelölni a fogalmakat és asszociációk közvetítésével felébreszteni az érzelmeket. Tulajdonképpen minden nyelvnek ez a kettős oldala van, amit logikai és lélektani vonásnak lehetne nevezni. A szavak logikai feladata tehát az, hogy a fogalmakat és azok viszonyait kifejezzék, ábrázolják, lélektani feladatuk az, hogy asszociációk keltésével a szükséges érzelmet, mint a lélek belső állapotának mozzanatát felébresszék. Stílusnak nevezzük a gondolatoknak olyan nyelvbeli kifejezését, amely úgy a logikai jelentés ábrázolása, mint az érzelem felkeltése szempontjából egyénileg legalkalmasabb" (449).

Formai szempontból kötött és kötetlen stílust különböztet meg, tartalmi szempontból kifejtőt és költőit; a kifejtő stílus alaptényezője a fogalom, a költői stílusé a kép. A szónoki nyelv a kifejtő és a költői között van, genus mixtum. Már itt megfogalmazza azt a gondolatát, hogy a beszéd mint müalkotás a drámához áll a legközelebb. A beszéd is, a dráma is etikai értékek csatája és győzelme. „A beszédnek is, mint a drámának, alapvonása a fokozás vagy emelkedés, azaz a gondolatok következményeinek csatasorba való kifejlődése, megütközése és győzedelme. Amelyik beszéd nem emelkedik, éppen olyan rossz, mint az a dráma, ahol a cselekvény nem fejlődik. [...] A beszéd még a csirájában levő és egy ember előadásában megjelenő dráma, vagyis dráma a gondolat síkjában. Ezt a gondolati drámát azonban legerősebben az választja el az igazi drámától, hogy praktikus célt szolgál, hogy nevel. A szónoki nyelv tehát fejteget, mikor valamit meg akar világosítani, fest, ahol a hallgatóságnak látnia vagy éreznie kell, magával ragad, mikor az érzelmeket tetté akarja változtatni. Ahol oktat, szónoki próza, ahol az érzelmekhez fordul, ott szónoki poézis, a maga egészében mind a kettő és mégis egyik sem teljesen, hanem különálló valami: szónoki nyelv" (453). A régiek tulajdonképpen eszerint különböztették meg a három stílusnemet: az egyszerüt, a közepest és a fennköltet. A szóképeket és az alakzatokat hatásuk alapján osztályozza (mint Zlinszky Aladár: A szóképekröl, 1911, modern kiadása: Szathmári István: A magyar stilisztika útja. Budapest, 2008, 177-197).

Érdekfeszítően ír az előadásmódról is. Stílusa szellemes, helyenként ironikus: „Van tehát a protestáns keresztyén igehirdetőnek is lelke, és e léleknek vannak küzdelmei, harcai, válságai és diadalmai. A zengő torkú, zsíros szívű, vörös nyakú kálvinista pap, ki vasárnaponkint olyanokat kurjant az örökkévaló dolgokról, hogy lehull a templom vakolata s még a köböl faragott civis is pislogni kezd, csak önmaga nem érez e mívelet alatt a fizikai mívelet erőlködésén kívül semmi lelki emóciót: szánalmas, szomorú látvány, még ha úgy füstölög is a gőgtől és az önimádattól. 
Ez a típus korlátoltabb annál, mintsem megértené, hogy neki legelső sorban össze kellene roskadnia, belső, szent tapasztalásokat tennie s azután megszólalni halk, alázatos hangon, hogy elbeszélje a benne lett csodadolgokat. Ki kell ennek a típusnak pusztulnia - csak a magyar kálvinizmus ki ne pusztuljon vele együtt. De én hiszem, hogy a magyar kálvinizmus nem fog e spirituális bölényekkel együtt kipusztulni. Nem, mert ha igehirdetőit eddig kibírta: nincs az a hatalom, amely úrrá lehessen felette" (278-279).

\section{RETORIKAELMÉLETI MÜVEI}

A retorikaelméletet néhány rövid, de annál gazdagabb tartalmú tanulmánnyal gazdagította. Azt gondoljuk, hogy idejét lekötötte a szolgálat: nagyon sok beszédet mondott el, sokféle alkalomból. Tanulmányai egységes szemléletet foglalnak össze, sok előremutató gondolattal:

(1) Felismerte, hogy a technikai vívmányok ismét előtérbe helyezték a beszédet, a másodlagos szóbeliséget (Walter Ong7 erről jóval később ír), „A papiroskorra jő az antenna-korszak" - írja Ars Hungarica címü értekezésében 1934-ben. ${ }^{8}$

(2) A beszéd mint müalkotás címü retorikaelméleti tanulmányában (1935) azt fejtegeti, hogy a beszéd logikai dráma. ${ }^{9}$ Minden műalkotásban ellentétek feszülnek, s feloldásuk a művészi siker. A feszültség döntő fontosságú a drámában és a beszédben, de míg a drámában a megvalósítás az egész színházé, a beszédben egyetlen emberé: aki akkor teremti és adja elő az egész müvet. A teremtéshez az szükséges, hogy bevonja hallgatóságát, s attól kezdve a nagy logikai dráma a hallgatóság lelkében zajlik: „Mert nemcsak arra megy ám itt a játék, hogy egy causalis tétel finalis tétellé alakuljon át, hanem arra is, sőt igazán csak arra, hogy a hallgatóság más legyen: felszabadult, meggazdagodott, győzelmet nyert kollektív személy. A szónok csak billentyüzet; a sípok őserejében a hallgatóság közös lelkének ezer változatú szenvedélye zúg." ${ }^{\circ}$ A hallgatóság szerepének, jelentőségének felismerése - mint fentebb

\footnotetext{
${ }^{7}$ Walter J. Ong (1912-2003) amerikai filozófus, retorikus, jezsuita szerzetes. Leghíresebb műve: Orality and Literacy. The Technologizing of the Word. North Yorkshire, 1982; magyarul: Szóbeliség és írásbeliség. A szó technologizálása. Ford. Kozák Dániel. Budapest, 2010.

${ }^{8}$ Vígh Árpád: Retorika és történelem. Budapest, 1981, 353.

${ }^{9}$ A beszéd és a dráma azonosítása - jóval később - Kenneth Burke nagy témája. Öt, a drámára és a beszédre egyaránt jellemző kategóriát állapít meg, ezek: cselekvés, helyszín, cselekvő, eszköztár, cél - együttesüket pentásznak nevezi.

${ }^{10}$ Adamik - A. Jászó - Aczél: Retorika, 589.
} 
említettük - a 2o. század második felében lesz a retorikaelmélet egyik középponti témája (elsősorban Perelman müveiben).

(3) Elméleti szempontból másik jelentős tanulmánya: Szónoklás és igehirdetés (1937). Abból indul ki - mint 1964-ben Roland Barthes ${ }^{11}$-, hogy a retorika „ma már valóságos múmia”, elmúlt a retorikai életforma, s vele együtt meghalt a retorika mint tudomány. Ez azonban csak látszat, mert a világban olyan átrendeződések történnek, amelyek újra fogják éleszteni a retorikát: „beláthatatlan tömegeket kell párttá szervezni, hogy a világ előbbre menjen, és sorsunk fonala tovább gombolyodjék. ... Párt és népgyülés tagozódik kisebb keretű összejövetelekben, le egészen a néhány emberből álló összesúgásig. Itt eltűnik az akarati hatások, a nagy befolyásolások látható gépezete, és átmegy a sejtrendszerek négyszemközt való rábeszélésének és megnyerésének kikutathatatlan világába. A sok akarat egybefonásának világmozdító üzeme a tömegek nyilvános és az egyesek titkos rábírásának egymást támogató és kiegészítő módszerével végzi világ- és életalakító munkáját." ${ }^{12} \mathrm{Az}$ élő szó hatalma megnőtt. „Egy új tudomány alakult, a tömegek lélektana, amely azt mutatja, hogy a különböző összetételű közösségekben, a társaságok, öszszejövetelek, népgyülések, nemesek és csőcselékek lelki életében miképpen jönnek létre közös érzések, közös látások és közös elhatározások. A pedagógia nem helyezi be az egyént légüres térbe, hanem a közösségből érti meg, sőt nem is az egyének, hanem a nagy emberi közösségek nevelésével foglalkozik, s e munkájának jelentős része, az élő szó útján történő céltudatos, egységes és zárt nevelői hatás vizsgálata, az, ami lényegében nem más, mint a retorikának mindenkori tárgya: az életalakító gondolatközlés elmélete. [...] Mindezekből az következik, hogy az ékesszólás tudományának csak az iskolás formája: a régi jó retorika halt meg, de az élet tényei és a hozzájuk füződő tudományos problémák merőben új arculattal, de a régi erővel és igénnyel állnak velünk szemben, várván a maguk emberére, aki az élő szó hatástudományát, a célzatos és müvészi beszéd elméletét önálló tudománnyá tegye..." ${ }^{13}$

Öt igazolja a legújabb amerikai összefoglalás, a The Sage Handbook of Rhetorical Studies (ed. Andrea A. Lunsford, Los Angeles, 2009), melynek nagy témái a pedagógia, a politika, a kampányok, a média és a retorika kapcsolata. A továbbiakban

${ }^{11}$ Roland Gérard Barthes (1915-1980) francia irodalmár. 1964-65-ben retorikai szemináriumot tartott. Ennek anyaga magyarul is megjelent: A régi retorika. Emlékeztető. Ford. Szigeti Csaba. In Thomka Beáta (szerk.): Az irodalom elméletei. III. Pécs, Jelenkor, 1997. Eredeti: „L'Ancienne rhétorique, Aide-mémoire." Communications, 16, 1970, 172-229.

${ }^{12}$ Ravasz László: Szónoklás és igehirdetés. A Debreceni Tisza István Tudományos Társaság I. Osztályának Kiadványai. VII. kötet, 4. füzet. Debrecen, 1937, 4.

${ }^{13}$ Uo. 4-5. 
azt fejtegeti, hogy a beszéd hatalma négy tényezőből tevődik össze, ezek: az alkalom, az élő szó, a hatás és a beszélő. Az alkalom tkp. a retorikai szituáció (használja is a szituáció terminust, lásd Lloyd Bitzer), az élő szó a másodlagos szóbeliségre utal (Walter Ong), a hallgatóság szerepével pedig kiemelten foglalkozik a mai retorika.

\section{BESZÉDEI}

Beszédei a szónoklás minden erényét egyesítik: a szilárd logikát, a világos előadásmódot, az igényes magyar nyelvet, a szemléletességet, a mozgalmasságot és az érzelmek széles skáláját. ${ }^{14}$ Főbb művei: Gondolatok, 1921 (4. kiad. 1938); Az emberélet útjának felén (1924); Beta és Omega, 1-2. (1933); Legyen világosság, 1-3. (1938); Korbán. Beszédek, irások I-II. (1942); Emlékezéseim (1992); Ószövetségi magyarázatok (1994). Egészen másképp alakult volna retorikai irodalmunk és gyakorlatunk sorsa, ha a kommunista hatalom nem némította volna el, ha átmentődött és folytatódott volna az a retorikaelméleti munkásság, amelyet megteremtett. Az alábbiakban egyetlen közérdekü témájú beszédét közöljük rövid elemzéssel, hogy némiképp érzékeltessük: nemcsak az elméletnek, hanem a gyakorlatnak is mestere volt. A bevezetésben említettem, hogy sok alkalmi, például házassági, temetési beszédet mondott. Idézzünk itt egy házassági beszédet.

\section{Eleve elrendelés a házasságban}

Példabeszédek 18, 22: Megismerte a jót, aki talált feleséget, és vett jóakaratot az Úrtól.

Mint minden a világon, úgy a szent házasság is akkor nyeri meg igazi értelmét, és kerül a maga méltó helyére, ha az eleve elrendelés szempontjából nézzük. Alapigénk éppen erre tanít.

Sokan azt hiszik, hogy a házasság véletlen. Ezzel esetlegessé teszik, megrontják fontosságát, elveszik isteni kényszerüségét, s vagy múló viszonnyá, vagy kiszámíthatatlan balesetté változtatják. Mások úgy gondolkoznak, hogy a házasság egészen tőlünk függ. Az lesz a párunk, akit mi akarunk, s olyan lesz a házaséletünk, amilyenné mi alakítjuk. Pogány beszéd ez is, mint az a közmondás, hogy ki-ki a maga szerencséjének kovácsa. A házasság sokkal nagyobb dolog, hogysem tőlünk függene, $s$ bár benne sok fordul meg rajtunk, mégis felettünk álló forrásból ered, és tőlünk független mederben halad tova a házasélet patakja.

\footnotetext{
${ }^{14}$ Adamik - A. Jászó - Aczél: Retorika, 173-175.
} 
Alapigénk vonja helyes világításba a házasságot, amidőn arra utal, hogy a házasság Istentől ered és az Ö eleve elrendelésének egyik pászmája. Mikor még föld és ég sem volt, már eldöntötte egy örök határozat, hogy ti az idő egyik pontján egymásra találtok, és kézen fogva az Úr orcája előtt megálltok. Életetek minden pillanata közeledés volt e nap felé, melyet ezentúl vagy úgy visztek magatokkal, mint a patak a belefutott csermelyt, vagy az üzött vad testébe tört nyílvesszőt.

Megtörténhetik, hogy ez a dekrétom már első találkozáskor felvillan a megfényesedő szemek előtt, de megtörténhetik az is, hogy két ifú évekig él egymás társaságában, barátok vagy idegenek, talán éppen ellenségek, és nem tudják, hogy egyszer kiderül a nagy végzés, és ők megtalálják egymást.

Nem tűnő véletlen, nem emberi erőfeszítés: Isten örök rendelése eredteti a házasságot.

Ebből következik az, hogy igazi hitvestárs a másikban Isten legnagyobb ajándékát ismeri fel. Addig nem tudjátok, ki a másik, míg nem Isten kezéből fogadjátok el, mint az élet legnagyobb ajándékát. Tehát jó hitvesnek lenni nem érdem, hanem kegyelem, s érte nem embernek, hanem Istennek tartozunk hálaadással. Milton Elveszett Paradicsom című művében éppen az a legszebb részlet, amidőn Ádám és Éva egymás felé közelednek, mint két egymásnak ajándékozott csillag, mint két egymás számára teremtett világ.

De a házasság nemcsak ajándék, amit elfogadok, hanem küldetés, amit végrehajtok. Isten az örökkévalóságból azzal bocsátott el, hogy szolgálj egy másik lényt, áldozd neki oda a szívedet, és saját életed árán is életét gazdagítsd meg és ékesítsd fel. Ezért a házastársi szolgálat végső ihletője, nagy parancsolója maga az Isten. Ö rendelte az emberi szívet erre a szolgálatra, és Ö ad erőt e szolgálat betöltésére.

Fogjátok meg egymás kezét, és esküszóval tegyetek vallást arról, hogy házasságotok forrása és torkolata Isten örök kegyelme.

A házassági beszéd szermó, azaz prédikáció, az egyházi beszéd kategóriájába tartozik. Ez a beszéd azonban emlékeztet a homíliára, mivel egy bibliai idézetből indul ki. Célját tekintve tanácsadó beszéd, hiszen a házasság szentségének elfogadására és az a szerinti életre buzdít. Az alkalomhoz is illik: rövid és tömör.

Ha az érvelés szempontjából vizsgáljuk, azt mondhatjuk, hogy a beszéd egyetlen retorikai körülírásos definíció: a házasság Isten örök kegyelmétől függő eleve elrendelés, ajándék és szolgálat.

A beszéd klasszikus szerkezetü, részei: tétel, megelőzés (prolépsis), háromrészes érvelés, befejező buzdítás. A bevezető gondolat röviden magyarázza az alapigét (a 
sententia sacrát). A szónok elöreveszi az ellenkező vélekedések és a közvélekedés cáfolatát, mintegy megelözve az esetleges ellenvéleményeket; ez gondolatalakzat: megelőzés, görög terminussal prolépsis. A házasság tehát nem tőlünk függ, bár „sok fordul meg rajtunk”, vagyis bizonyos korlátok között azért érvényesül akaratunk. Ezután következik az alapige kifejtése: a házasság Istentől ered, Isten legnagyobb ajándéka, küldetés is, azaz „egy másik lény” szolgálata. A meghatározás leghatásosabb összetevője az ajándék-metafora, ezt színezi a Miltontól vett két szép hasonlattal dúsított jelenet.

Az egész beszéden végigvonul egy ősi kép: a házasélet és a folyóvíz azonosítása: forrás, patak, torkolat. A beszéd elején, a bizonyítás előtt: „felettünk álló forrásból ered, és tőlünk független mederben halad tova a házasélet patakja”. Majd a lezáró esküben: „esküszóval tegyetek vallást arról, hogy házasságotok forrása és torkolata Isten örök kegyelme".

Ravasz László beszéde azért remekmü, mert szerkezete, érvelése világos, ugyanakkor szemléletes is: a gyönyörködtető középső stílus mintája. Igazi szónoki meghatározás: szabadabb, teljesebb, ékesebb, mint a logikai definíció; gondolatmenete eredeti, érdekes és tanulságos a ma embere számára is. 